\title{
Effect of Plant Growth Regulators and Chemicals on Seedling Growth of Rough Lemon (Citrus jambhiri L.) under Hydroponic Condition
}

\author{
Arghistani Sanaullah", B. N. Hazarika, L. Wangchu and P. Sarma \\ Department of Fruit Science, College of Horticulture and Forestry, Central Agricultural \\ University, Pasighat- 791102, Arunachal Pradesh, India \\ *Corresponding author
}

\section{A B S T R A C T}

K e y w o r d s
PGRs, Chemicals,
Pre-sowing,
Seedling growth,
Rough lemon
Article Info
$\begin{aligned} & \text { Accepted: } \\ & 17 \text { August } 2020 \\ & \text { Available Online: } \\ & \text { 10 September } 2020\end{aligned}$

An experiment was conducted during the year 2019-20 under hydroponic condition at Fruit Science laboratory, Department of Fruit Science, College of Horticulture and Forestry, CAU, Pasighat, Arunachal Pradesh to evaluate the influence of pre-sowing treatments on seedling growth of rough lemon rootstock. The experiment was laid out in Completely Randomized Design with thirteen treatments replicated thrice. The various concentrations of growth regulators and chemicals viz., $\mathrm{GA}_{3}, \mathrm{NAA}, \mathrm{KNO}_{3}$ and Thiourea were used to treat the seeds of rough lemon and further observation were taken for 90 DAS. The results indicated that the maximum height of seedling $(14.35 \mathrm{~cm})$, girth of stem $(1.93 \mathrm{~mm})$, length of root $(8.57 \mathrm{~cm})$, number of roots/seedling $(10.44)$, number of leaves/seedling (3.66), fresh weight of shoot $(0.348 \mathrm{~g})$, dry weight of shoot $(0.119 \mathrm{~g})$, fresh weight of roots $(0.109 \mathrm{~g})$ and dry weight of roots $(0.039 \mathrm{~g})$ were recorded in seeds treated with $\mathrm{GA}_{3} 150 \mathrm{ppm}$ for 12 hours. Therefore, it can be concluded that the $\mathrm{GA}_{3}$ at $150 \mathrm{ppm}$ was found best for vegetative growth.

\section{Introduction}

Rough lemon (Citrus jambhiri L.) has been widely used rootstock amongst the citrus rootstocks for the scion cultivars in India. This rootstock is considered to have probably originated from North Eastern Region of India. Rough lemon is preferred due to high resistant to Citrus Tristeza Virus (CTV), citrus exocortis as well as for its tolerance against drought and salt. This rootstock is greatly used for high production per plant and large size tree with well-developed root system that enables the plant to withstand unfavorable soil conditions. Trees budded on rough lemon may produce poor quality fruits due to less juice and low acid content in the fruit, while the fruits get earliest maturity and large size. Rough lemon is more susceptible to gummosis and root rot and has poor tolerance to Phytophthora (Naqvi, 2000).

The seedlings are commonly used as a rootstock for various desirable varieties. The rootstock which is used for scion is most important and affecting tree productivity, fruit quality, plant growth, longevity of tree and susceptibility of the trees against various pests 
and diseases. Hence, the vigorous rootstocks are required to be selected for grafting or budding having high degree of compatibility with the scion, tolerance to drought and frost, and resistant to common viruses particularly tristeza, fungal diseases and nematodes. Moreover, rootstock may influence the plant nutrient status of scions grafted on them such as leaf mineral elements are affected by rootstocks (Toplu et al., 2008). Rootstock is also responsible to absorb water and nutrients from the soil. Many times citrus species are infected with systemic diseases caused by fungi, mycoplasma, viruses, bacteria, etc. The pathogen does not always lead to the death of the plant, but pathogen significantly reduces the quality of fruits and yield of the plant. Therefore, selection of proper rootstock seedling is one of the most important considerations for raising of quality budded or grafted planting materials.

Recently, growth regulators and chemicals have gained much attention for their role in growth and development of plants as well as seed germination. Plant hormones have most important functions in controlling and coordinating cell division, growth and differentiation (Hooley, 1994). Application of different plant growth regulators and chemicals has shown significant effect on seed germination and seedling growth in various researches. Based on these facts, the present investigation was undertaken to improve better seedling growth of rough lemon through certain seed treatments.

\section{Materials and Methods}

The present experiment entitled Effect of plant growth regulators and chemicals on seedling growth of rough lemon (Citrus jambhiri L.) was conducted during the year 2019-20 at Fruit Science Laboratory under low cost hydroponic condition, Department of Fruit Science, College of Horticulture and
Forestry, CAU, Pasighat, Arunachal Pradesh. The experiment was carried out following Completely Randomized Design with thirteen treatments viz. $\mathrm{T}_{1}-\mathrm{GA}_{3} 50 \mathrm{ppm}, \mathrm{T}_{2}-\mathrm{GA}_{3}$ $100 \mathrm{ppm}, \mathrm{T}_{3}-\mathrm{GA}_{3} 150 \mathrm{ppm}, \mathrm{T}_{4}$ - NAA 50 ppm, $\mathrm{T}_{5}$ - NAA $100 \mathrm{ppm}, \mathrm{T}_{6}$ - NAA $150 \mathrm{ppm}$, $\mathrm{T}_{7}-\mathrm{KNO}_{3} 0.5 \%, \mathrm{~T}_{8}-\mathrm{KNO}_{3} 1.0 \%, \mathrm{~T}_{9}-\mathrm{KNO}_{3}$ $1.5 \%, \mathrm{~T}_{10}$ - Thiourea $0.5 \%, \mathrm{~T}_{11}$ - Thiourea $1.0 \%, \mathrm{~T}_{12}$ - Thiourea $1.5 \%$ and $\mathrm{T}_{13}$ - control (Distilled water). The treatments replicated trice using 30 seeds in each treatment of a replication. The seeds were soaked for 12 hours and sown during last week of November, 2019. The seedlings were allowed to grow for three month. After three months, five representative seedlings from each replication of a treatment were selected for measuring growth parameters; height of seedling, girth of stem, length of root, number of roots/seedling, fresh weight of shoot, dry weight of shoot, fresh weight of roots, dry weight of roots, number of leaves/seedling.

\section{Results and Discussion}

\section{Height of seedling}

At 90 days after sowing, the maximum height of seedling $(14.35 \mathrm{~cm})$ was noted with $\mathrm{GA}_{3}$ $150 \mathrm{ppm}$ which was statistically at par with the treatment $\mathrm{KNO}_{3}$ at $1.5 \%$. However, the lowest rank of seedling height was observed with control. The enhancement in seedling height with $\mathrm{GA}_{3}$ treatment might have occurred due to increased osmotic uptake of nutrients by this hormone which caused cell elongation and enhancement of seedling height (Shanmugavelu, 1966). Apart from improving germination $\mathrm{GA}_{3}$ treatment also increased the subsequent growth of seedling which is due to the fact that $\mathrm{GA}_{3}$ induces the hydrolysis of sugar in the seed which is than utilized in the synthesis of auxin and proteins. It is cleared that the auxin is necessary for the growth of young seedling and proteins are utilized by developing seedlings as a 
nutritional source and in subsequent phases of growth and development. The results are in close conformity with the findings of Jadhav et al., (2019) in Rangpur lime, Jadhav et al., (2015) in custard apple and Kumar et al., (2008) in mango.

\section{Girth of stem}

Table 1 reveals that the girth of seedling stem at 90 days after sowing was found maximum $(1.93 \mathrm{~mm})$ when seeds were treated with $\mathrm{GA}_{3}$ at $150 \mathrm{ppm}$, whereas the minimum girth of seedling stem $(1.65 \mathrm{~mm})$ was recorded with control. The increased girth of seedling stem obtained from $\mathrm{GA}_{3}$ presoaked seeds might be due to the elongation of internodes induced by the cell elongation, increase in cell size and rapid cell division which resulted in increased girth of seedling stem. Increase in stem girth may also be possible due to stimulation of cambium and its immediate cell progeny as observed by Dhankhar and Singh (1996) in aonla. This type of result was also observed by Agha et al., (1990) in sour orange and citrange rootstock, and Rahangdale et al., (2019) in custard apple.

\section{Length of root}

It is observed from the Table 1 that treatment with $\mathrm{GA}_{3}$ at $150 \mathrm{ppm}$ concentration (T3) led to the maximum length of root $(8.57 \mathrm{~cm})$ at 90 days after sowing which was significantly higher than all other treatments, while the minimum length of root was recorded under control. Increase in the length of roots may be due to the $\mathrm{GA}_{3}$ activation in the more production of photosynthates and their translocation to root zone through phloem, causing elongation of roots (Vachhani et al., 2014). Furthermore, the enhancement in some growth parameters such as number of leaves/seedling, leaf area, fresh and dry weights of shoots and roots with the previous treatments could be attributed to their effect on the increase root length as well as plant length. These results corroborate with the findings of Singh et al., (2017) in kagzi Lime and Al-Hawezy (2015) in loquat.

\section{Number of roots/seedling}

The data in the Table 1 indicated that the maximum number of roots per seedling (10.44) was recorded with $\mathrm{GA}_{3} 150 \mathrm{ppm}$ at 90 days after sowing. However, the minimum number of roots per seedling (3.77) was obtained under control. This improvement in number of roots per seedling might be due to the vigorous root growth. Hence, the vigorous growth might have improved the root growth, resulting in more number of roots per seedling. The above results are in conformity with Dilip et al., (2017) in Rangpur lime and Anjanawe et al., (2013) in papaya.

\section{Number of leaves/seedling}

It is evident from the data presented in Table 1 that the highest number of leaves (3.66) was recorded with the treatment $\mathrm{GA}_{3} 150 \mathrm{ppm}$, while the lowest number of leaves was observed with treatment control. The increase in the number of leaves per seedling in $\mathrm{GA}_{3}$ $150 \mathrm{ppm}$ was possibly due to the movement of $\mathrm{GA}_{3}$ to the shoot apex which promoted cell division and cell growth apparently leading to increased development of young leaves (Salisbury and Ross, 1988). In addition, the height and vigorous growth of seedling induced by the $\mathrm{GA}_{3}$ treatment facilitate more production of branches and more number of leaves. The result is in agreement with findings of Joshi et al., (2015) in lime, Brijwal and Kumar (2013) in guava.

\section{Fresh and dry weight of shoot}

At 90 days after sowing, the treatment $\mathrm{GA}_{3}$ $150 \mathrm{ppm}$ produced more fresh and dry weight of shoot (0.348 $\mathrm{g}$ and $0.119 \mathrm{~g}$, respectively) 
which was significantly superior over control. shoot $(0.109 \mathrm{~g}$ and $0.038 \mathrm{~g}$, respectively) was Significantly less fresh and dry weight of recorded under treatment control.

Table.1 Effect of plant growth regulators and chemicals on seedling growth of rough lemon

\begin{tabular}{|c|c|c|c|c|c|c|}
\hline Tr. No. & Treatments & $\begin{array}{c}\text { Height of } \\
\text { seedling (cm) }\end{array}$ & $\begin{array}{c}\text { Girth of } \\
\text { stem }(\mathbf{m m})\end{array}$ & $\begin{array}{c}\text { Length of } \\
\text { root }(\mathbf{c m})\end{array}$ & $\begin{array}{c}\text { Number of } \\
\text { roots/seedling }\end{array}$ & $\begin{array}{c}\text { Number of } \\
\text { leaves/seedling }\end{array}$ \\
\hline $\mathbf{T}_{\mathbf{1}}$ & $\mathrm{GA}_{3}(50 \mathrm{ppm})$ & 11.41 & 1.68 & 5.97 & 6.89 & 2.66 \\
\hline $\mathbf{T}_{\mathbf{2}}$ & $\mathrm{GA}_{3}(100 \mathrm{ppm})$ & 11.57 & 1.89 & 6.96 & 7.33 & 3.44 \\
\hline $\mathbf{T}_{\mathbf{3}}$ & $\mathrm{GA}_{3}(150 \mathrm{ppm})$ & 14.35 & 1.93 & 8.57 & 10.44 & 3.66 \\
\hline $\mathbf{T}_{\mathbf{4}}$ & $\mathrm{NAA}(50 \mathrm{ppm})$ & 9.05 & 1.70 & 5.37 & 4.33 & 2.55 \\
\hline $\mathbf{T}_{\mathbf{5}}$ & $\mathrm{NAA}(100 \mathrm{ppm})$ & 10.21 & 1.75 & 6.46 & 5.66 & 3.00 \\
\hline $\mathbf{T}_{\mathbf{6}}$ & $\mathrm{NAA}(150 \mathrm{ppm})$ & 9.20 & 1.68 & 6.36 & 5.11 & 2.66 \\
\hline $\mathbf{T}_{\mathbf{7}}$ & $\mathrm{KNO}_{3}(0.5 \%)$ & 9.16 & 1.72 & 6.03 & 6.11 & 2.89 \\
\hline $\mathbf{T}_{\mathbf{8}}$ & $\mathrm{KNO}_{3}(1.0 \%)$ & 10.65 & 1.87 & 7.38 & 7.00 & 2.77 \\
\hline $\mathbf{T}_{\mathbf{9}}$ & $\mathrm{KNO}_{3}(1.5 \%)$ & 13.94 & 1.90 & 8.50 & 8.22 & 3.11 \\
\hline $\mathbf{T}_{\mathbf{1 0}}$ & Thiourea $(0.5 \%)$ & 10.16 & 1.89 & 5.64 & 6.33 & 3.00 \\
\hline $\mathbf{T}_{\mathbf{1 1}}$ & Thiourea $(1.0 \%)$ & 9.04 & 1.81 & 7.16 & 5.11 & 3.33 \\
\hline $\mathbf{T}_{\mathbf{1 2}}$ & Thiourea $(1.5 \%)$ & 10.29 & 1.70 & 6.85 & 6.00 & 3.00 \\
\hline $\mathbf{T}_{\mathbf{1 3}}$ & Control & 8.60 & 1.65 & 5.32 & 3.77 & 2.44 \\
\hline & S.Em $\mathbf{}$ & 0.62 & 0.04 & 0.51 & 1.01 & 0.17 \\
\hline & $\mathbf{C}$ C.D 5\% level & 2.11 & 0.14 & 1.72 & 3.38 & 0.54 \\
\hline
\end{tabular}

Table.2 Effect of plant growth regulators and chemicals on seedling growth of rough lemon

\begin{tabular}{|c|c|c|c|c|c|}
\hline Tr. No. & Treatments & $\begin{array}{c}\text { Fresh weight of } \\
\text { shoot } \mathbf{g} \text { ) }\end{array}$ & $\begin{array}{c}\text { Dry weight of } \\
\text { shoot } \mathbf{( g )}\end{array}$ & $\begin{array}{c}\text { Fresh weight of } \\
\text { root (g) }\end{array}$ & $\begin{array}{c}\text { Dry weight of } \\
\text { root (g) }\end{array}$ \\
\hline $\mathbf{T}_{\mathbf{1}}$ & $\mathrm{GA}_{3}(\mathbf{5 0} \mathrm{ppm})$ & 0.161 & 0.044 & 0.072 & 0.027 \\
\hline $\mathbf{T}_{\mathbf{2}}$ & $\mathrm{GA}_{3}(100 \mathrm{ppm})$ & 0.257 & 0.093 & 0.088 & 0.028 \\
\hline $\mathbf{T}_{\mathbf{3}}$ & $\mathrm{GA}_{3}(150 \mathrm{ppm})$ & 0.348 & 0.119 & 0.109 & 0.039 \\
\hline $\mathbf{T}_{\mathbf{4}}$ & $\mathrm{NAA}(50 \mathrm{ppm})$ & 0.120 & 0.040 & 0.063 & 0.025 \\
\hline $\mathbf{T}_{\mathbf{5}}$ & $\mathrm{NAA}(100 \mathrm{ppm})$ & 0.162 & 0.057 & 0.061 & 0.024 \\
\hline $\mathbf{T}_{\mathbf{6}}$ & $\mathrm{NAA}(150 \mathrm{ppm})$ & 0.130 & 0.042 & 0.068 & 0.026 \\
\hline $\mathbf{T}_{\mathbf{7}}$ & $\mathrm{KNO}_{3}(0.5 \%)$ & 0.218 & 0.081 & 0.091 & 0.030 \\
\hline $\mathbf{T}_{\mathbf{8}}$ & $\mathrm{KNO}_{3}(1.0 \%)$ & 0.245 & 0.098 & 0.086 & 0.027 \\
\hline $\mathbf{T}_{\mathbf{9}}$ & $\mathrm{KNO}_{3}(1.5 \%)$ & 0.334 & 0.113 & 0.096 & 0.033 \\
\hline $\mathbf{T}_{\mathbf{1 0}}$ & Thiourea $(0.5 \%)$ & 0.244 & 0.089 & 0.070 & 0.027 \\
\hline $\mathbf{T}_{\mathbf{1 1}}$ & Thiourea $(1.0 \%)$ & 0.214 & 0.066 & 0.075 & 0.026 \\
\hline $\mathbf{T}_{\mathbf{1 2}}$ & Thiourea $(1.5 \%)$ & 0.146 & 0.047 & 0.066 & 0.024 \\
\hline $\mathbf{T}_{\mathbf{1 3}}$ & Control & 0.109 & 0.038 & 0.060 & 0.022 \\
\hline & S.Em \pm & 0.02 & 0.008 & 0.008 & 0.002 \\
\hline & C.D 5\% level & 0.058 & 0.026 & 0.027 & 0.008 \\
\hline
\end{tabular}


Basically, the increased weight of seedling was associated to higher germination, early seedling emergence and better seedling growth. $\mathrm{GA}_{3}$ as a plant growth regulator influences in stimulating cell division, cell elongation, auxin metabolism, cell wall plasticity and permeability of cell membrane which could have resulted in enhanced growth and accumulation of dry matter in various part of seedling. The results are supported with the findings of Jaiswal et al., (2018) in kagzi lime, Shukla et al., (2012) in kagzi lime and Chiranjeevi et al., (2017) in aonla.

\section{Fresh and dry weight of roots}

At 90 days after sowing, the treatment $\mathrm{GA}_{3}$ $150 \mathrm{ppm}$ obtained maximum fresh and dry weight of roots $(0.109 \mathrm{~g}$ and $0.039 \mathrm{~g}$, respectively) which was significantly superior over control. Significantly less fresh and dry weight of shoot $(0.060 \mathrm{~g}$ and $0.022 \mathrm{~g}$, respectively) was recorded under control. The promising effect of $\mathrm{GA}_{3}$ on fresh weight of roots might be due to the acceleration in the translocation and assimilation of auxins, the assimilation and redistribution of materials in plants cause better growth and vegetative characters which enhance the growth attributes (Pandiyan et al., 2011). $\mathrm{GA}_{3}$ might have also increased the auxin level in the roots which induces tap root length and number of secondary and fibrous roots through stimulation of more root initiation, more nutrient uptake and root cell elongation which results in more fresh and dry weight. In addition, increased growth is a result of increased dry matter accumulation. These results are in conformity with findings of Patil et al., (2012) in Rangpur lime, Khatana et al., (2015) in acid lime cv. kagzi lime and Abbas et al., (2015) in white succary mango (Table 2).
It can be concluded that, in different presowing treatments the seeds soaked with $\mathrm{GA}_{3}$ at $150 \mathrm{ppm}$ solution for 12 hours had shown better effect in most of the growth parameters of rough lemon seedlings, and this treatment was at par with $\mathrm{KNO}_{3}$ at $1.5 \%$.

\section{References}

Abbas, M.T., Seif, M.I., Gomaa, A.M., and Nada, E.E.M. 2015.Effect of seed husk, $\mathrm{GA}_{3}, \mathrm{KNO}_{3}$ and seed orientation in seedbed on germination characters of white succary mango seeds. Hortscience J. Suez Canal Univ. 3(1): 55-60.

Agha, J.T., Nasir, R.F., and Mohamad, A.R.S. 1990.Effect of stratification and $\mathrm{GA}_{3}$ on seed germination of sour orange and citrange rootstock. Mesopotamia J. Agric. 22(2): 35-43.

Al-Hawezy, S.M.N. 2015.The role of the different concentrations of $\mathrm{GA}_{3}$ on seed germination and seedling growth of Loquat (Eriobotrya japonica L.). Zanco J. Pure \& Appl. Sci. 27(4): 65-70.

Anjanawe, S.R., Kanpure, R.N., Kachouli, B.K., and Mandloi, D.S. 2013. Effect of plant growth regulators and growth media on seed germination and growth vigour of papaya. Ann. Plant and soil Res. 15(1): 3134.

Brijwal, M., and Kumar, R. 2013.Studies on the seed germination and subsequent seedling growth of Guava (Psidium guajava L.).Indian J. Agric. Res. 47(4): 347-352.

Chiranjeevi, M.R., Muralidhara, B.M., Sneha, M.K., Shivan and Hogal 2017.Effect of growth regulators and biofertilizers on germination and seedling growth of aonla (Emblica officinalis Gaertn). Int. J. Curr. Microbiol. App. Sci. 6(12): 1320-1326.

Dhankhar, D.S., Singh, M. 1996. Seed germination and seedling growth in aonla (Phyllanthus emblica Linn.) as influenced by gibberellic acid and thiourea. Crop Res. 12(3): 363-366.

Dilip, W.S., Singh, D., Moharana, D., Rout, S., and Patra, S.S. 2017.Effect of gibberellic acid (GA) different concentrations at 
different time intervals on seed germination and seedling growth of Rangpur lime. $J$. Agroecol. Nat. Reso. Manag. 4(2): 157-165.

Hooley, R. 1994. Gibberellins: Perception, transduction and responses. Plant Mol. Biol. 26(5): 1529-1555.

Jadhav, A.C., Bhagure, Y.L., and Raundal, R.M. 2015. Effect of PGR, chemicals and plant extract on seed germination and seedling growth of custard apple (Annona squamosa). Asian J. Hort. 10(1): 184-186.

Jadhav, N.G., Tapkeer, P.B., and Deshmukh, H.S. 2019. Effect of growth regulators, chemical and organic wastes on height of seedling, number of seedlings per seed (extent of polyembryony), percent seedling attain buddable diameter and root length (primary and secondary) of Rangpur lime seedlings. Int. J. Chem. Stud. 7(3): 35963600 .

Jaiswal, S.B., Nainwal, R.V., Supekar, S.J., and Manel, S.B. 2018. The effect of growth regulators and chemicals on growth of kagzi lime (Citrus aurantifolia Swingle.) seedlings. Int. J. Curr. Microbiol. Appl. Sci. Special Issue-6: 940-944.

Joshi, P.s., Meshram, P.C., Sahoo, A.K., and Bhoyar, R.K. 2015.Effect of various plant growth promoting substances on seedling growth of Acid lime.Trends in biosci. 8(19): 5222-5225.

Khatana, K.J., Jadav, R.G., and Nehete, D.S. 2015. Influence of $\mathrm{GA}_{3}$ on germination and growth of acid lime cv. Kagzi lime seed (Citrus aurantifolia Swingle) under field as well as net house conditions. Asian. J. Hortic. 10(1): 11-16.

Kumar, H.S.Y., Swamy, G.S.K., Kanmadi, V.C., and Sowmaya, B.N. 2008. Effect of organics and chemicals on germination, growth and graft- take in mango. Asian $J$. Hortic. 3(2): 336-339.

Naqvi, S.A.M.H. 2000.Managing Phytophthora diseases in citrus. Indian Hort. 44(4): 5-9.

Pandiyan, R., Manivannan, K., and Kumar, R.A.
2011. Effect of growth regulators and age of root stocks on the propagation of Jack through grafting. Res. J. Agri. Sci. 2(2): 214-243.

Patil, S.R., Sonkamble, A.M., and Waskar, D.P. 2012.Effect of growth regulators and chemicals on germination and seedling growth of Rangpur lime under laboratory conditions. Int. J. Agric. Sci. 8(2): 494-497.

Rahangdale, P., Pandey, S.K., and Jayswal, D.K. 2019. Influence of $\mathrm{GA}_{3}$ and date of sowing on growth and development of custard apple seedlings. Int. J. Curr. Microbiol. App. Sci. 8(1): 1813-1821.

Salisbury, F.B. and Ross, C.W. 1988. Plant Physiology. CBS Publishers and Distributors, Delhi. Pp. 319-329.

Shanmugavelu, K.G. 1966. Studies on the effect of plant growth regulator on the seedling of some tree plant species. South Indian Hort. J. 14: 24-25.

Shukla, M., Singh, J., Namdeo, K.N., and Ahirwar, M.K. 2012. Effect of growth regulators and fungicide on seed germination and seedling vigour of Kagzi lime.Ann. Pl. Soil Res. 14(2): 175-176.

Singh, R., Gurjar, B., and Baghel, S.S. 2017. Seed germination and Seedling Vigour of kagzi Lime (Citrus aurantifoliaSwingle ) as influenced by growth regulators and fungicide. Int. J. Pure App. Biosci.4(5): 2105-2109.

Toplu, C., Kaplankiran, M., Demirkeser, T.H., and Yildiz, E. 2008. The effects of citrus rootstocks on Valencia late and rhode Red Valencia oranges for some plant nutrient elements. African J. Biotech. 7(24): 44414445.

Vachhani, K.B., Gohil, J.H., Pandey, R., and Ray, N.R. 2014. Influence of chemicals, PGR's and cow-dung slurry as seed treatment on germiability, growth and development of khirnee (Manilkara hexandra Roxb) under net house condition. Trends in Biosci. J. 7(14):1641-1643.

\section{How to cite this article:}

Arghistani Sanaullah, B. N. Hazarika, L. Wangchu and Sarma, P. 2020. Effect of Plant Growth Regulators and Chemicals on Seedling Growth of Rough Lemon (Citrus jambhiri L.) under Hydroponic Condition. Int.J.Curr.Microbiol.App.Sci. 9(09): 2353-2358.

doi: https://doi.org/10.20546/ijcmas.2020.909.294 